\title{
An Analysis of Translation Procedure in Translating Cultural Word
}

\author{
Apandi Apandi*, Devi Siti Sihatul Afiah \\ Faculty of Teaching and Educational Sciences \\ Unswagati Cirebon \\ Cirebon, Indonesia \\ *aapandi5@gmail.com,devy.sitiafiah@gmail.com
}

\begin{abstract}
This study aims to identify the types of cultural words contained in 5 story texts found in the Cirebon area of West Java and to identify the types of cultural words based on Newmark theory and how students use translation procedures. This study uses a qualitative descriptive approach that aims to make a description and explanation after analyzing the data that is on the translated text. There are two things that are examined in this study, the first is about the types of cultural words contained in Indonesian texts and the second is how the text is translated into English and classified using what procedures are used. Based on data analysis, it was found that there are four categories of culture based on Newmark theory, namely: (1) the category of material culture, (2) the category of social culture, (3) the category of art culture and (4) the category of ecological culture. The procedure used is dominated by the use of transference. The study has implication to enrich knowledge in the field of translation.
\end{abstract}

\section{Keywords: cultural word, translation}

\section{INTRODUCTION}

Translation activities continue to develop from pre-modern times to the present where all fields developing rapidly along with the development of science and technology. Translation occupies a very important role even though in its journey it has been very different between the old times which are still traditional and the current situation which has received various adjustments along with the development of the era where there have been many tools that assist in the translation process both online and offline dictionary applications. In practice, the use of translation technology needs calibration to get translation contents.

The translation of cultural words maintains a unique position because it requires special expertise in the form of adequate cross-cultural understanding because one cultural word is not necessarily found in its equivalent because indeed in the destination language there are no matters relating to these cultural words because every language lives in their respective cultures. Venuti states that in the translation of cultural concepts is needed additional information and a list of words that refer to parts of the text that use cultural words [1]. Whereas Lotman states no language can exist unless it is steeped in the context of culture; and no culture can exist which does not have at its center, the structure of natural language [2].
This implies that language and culture have a very close relationship and cannot be separated from one another.

In practice, cultural translation often gets into trouble because the words of culture are different from other words that are not culturally charged because a culture is not necessarily found the equivalent because there are not appropriate words so that additional information is needed or can also be found only in the same context. The use of appropriate word equivalents must also consider the cultural background of the source language [3]

Meanwhile research conducted by Nuryadi examined two things in the translation of cultural words, namely the category of cultural words contained in the source language and strategies in translating cultural words [4]. In its research, there were four cultural categories based on Newmark. those are (1) the category of material culture, (2) social culture, (3) artistry and (4) ecology [5]. While the two procedures used are (1) translating using the loan word and (2) translating with substitution.

Although a lot of people have examined the translation of cultural words before, this research is still relevant to add the diversity of facts found in the field. This research aims to find various types of cultural words and procedures used by students in the translation class.

\section{LITERATURE REVIEW}

\section{A. Definition of Translation}

Translation is the activity of transcribing written or oral messages from the text of one language into the text of another language [6]. The translated text is called the source text and the language is called the source language, while the text compiled by the translator is called the target text and the language is called the target language. The results of translation activities are called translations.

Translation involves two different languages. Therefore, the difference between the system of source language and target language is a major obstacle in translation [6]. Constraints faced become even greater if source language and target are two languages that are not allied. English and Indonesian are two languages that come from different families. Then, according to Vermer translation is a cross-cultural activity and 
a translator must understand types of culture at least two or more $[7,8]$.

Meanwhile, according to Nida and Charles stated that the translation is an attempt to re-express the message contained in the source language into the target language text with the closest and reasonable equivalent [4,9]. Meanwhile, Larson defines translation as the transfer of meaning from the source language into the target language [10]. So, it can be concluded that the translation is to divert a message in the form of words or a text from the source language into the target language [11].

\section{B. Translation Procedure}

Newmark suggests that there are several translation procedures that can be chosen to translate words with cultural significance [5]. They are:

- Transference, is the process of moving a word of the source language into the target language. The result of this procedure is in the form of a loan word. This procedure is usually used to translate people's names, regional names or geographical conditions.

- Cultural equivalent, the process of translation where the culture word from the source language a gotten equivalent in the form of the culture word in the target language.

- Descriptive translation (neutralization), is a combination of functional equivalent and descriptive equivalent.

- Naturalization, to adapt (adjust) the phonology and morphology of the vocabulary of the source language into the target language.

- Componential analysis. In general, culture words in the source language have more specific meanings than the target language. To produce translations that are close to the source language, the translator adds components that suit to the source language.

- Combination of several translation procedures (couplet), such as transference and cultural equivalent, and so on.

- International standard translation (accepted standard translation) uses internationally agreed translations, for example for terms such as President, Senate, and so on.

- Paraphrases, paraphrases, gloss, notes, in which the decomposition of a speech in another form (arrangement of words), in order to be able to explain the hidden meaning.

\section{Types of Cultural Words}

According to Newmark, culture is the way of life and its manifestation that the peculiar to a community that uses a particular language as its means of expression [5]. Culture is a view of life or way of life and its manifestations are characteristic of a society that uses a certain language as a tool to express it. So, the language used by a society is influenced by the way of life, and its specific manifestations in each community. Meanwhile, according to Hoed states that culture is a way of life that is manifested in behavior and results are seen from the material (artifacts) obtained through the process of habituation and learning in a society and passed on from generation to generation $[6,12]$.

Koentjaraningrat divides cultural forms into three, namely (1) culture in the form of ideas, (2) culture in the form of behavior or habits, and (3) cultural form in the form of objects (artifacts) [13]. This cultural form is contained in the human mind. Cultural forms include belief systems, social coating systems, arts, ceremonies, and cultural objects. A belief system is a belief that is believed by a community that something will be good or have a good impact if something it is believed, it was carried out and vice versa, something that would have a bad impact if it is violated. The social coating system is a grouping of people characterized by a way of life in the awareness of certain special privileges, such as caste issues and those related to it.

Art is a means used to express a sense of beauty from within the human psyche and serves to determine norms for regular behavior and carry on cultural customs and values. Ceremony is a social activity or patterned action, classified in the form of a social system, consisting of human activities that interact, relate and interact with each other from time to time according to certain patterns. Artifacts are archaeological objects or historical objects from the past, namely all objects that can be created or modified by humans can be moved.

Meanwhile Newmark divides culture into five: (1) ecology, (2) material culture, (3) social culture, (4) organization, customs, ceremonies, and concepts, and (5) habits and typical physical expressions [5]. Ecology covers flora, fauna, and landscape. Material culture includes food, clothing, houses or buildings, and transportation while social culture includes social stratification and social activities in leisure time. Organizations include social, political and governmental organizations.

\section{Translation of Culture Words}

Catford states that difficulties in translation can occur due to linguistic factors (linguistic untranslatability) and cultural factors (cultural untranslatability) [14]. Linguistic translation occurs if there is no substitute in target language for lexical or syntactic elements in source language. Catford's opinion above, then reinforced by Nida which states that there are five things that become obstacles in translation. They are [15]:

1) Ecology: The two languages used in two countries which located far apart and have different natural conditions will have different vocabulary, which concerns the season, weather, flora, fauna, and so on

2) Material culture: Each country has a different material culture. Material culture can be in the form of food, drinks, transportation equipment, objects used daily, clothing, and buildings.

3) Religious culture: The difference in religion embraced by the two nations can lead to differences in vocabulary between the two languages concerned. 
4) Social culture: The terms related to social culture, such as the terms kinship, marriage, work, entertainment, games, sports, etc.they are the terms that are not easy to be translated.

5) Language (Linguistic culture): Specific characteristics possessed by the languages involved in translation can also be obstacles in translation, such as differences in semantic systems and structures concerning phonology, morphology, syntax, and lexical. The culture terms referred is an object that is the result of the thought of a society.

\section{RESEARCH METHODOLOGY}

This study used qualitative descriptive approach that aims to make a description and explanation after analyzing the data that is on the translated text. In addition, [16] states that Descriptive research is to provide a systematic and factual description related to the data and its relationship with the phenomenon of the study (as cited from [17]. The text is the result of translation from Indonesian into English. Data collected in the two texts are classified based on cultural words and also classified how the words of culture are translated into the target language. Creswell states that qualitative research is a meaning to enrich and understand the meaning of individuals or groups to social or human problems [18]. And also Creswell states that qualitative research occurs in natural matters, where human behavior and events occur [18]. This model is done as a procedure to identify and describe a phenomenon based on facts. This research is a case study. the subject of this research is a collection of local stories that exist in 5 cultures of Cirebon, namely Kasepuhan, Petilasan Nyi Mas Gandasari, Plangon, Puser Bumi, and Sunyaragi. The data collection techniques in this study used triangulation: observation, questionnaire, and interview. After the data was collected, the researcher analyzed the data in several stages. They are classifying data according to the word culture based on Newark and determining the translation procedure based on the theory of translation procedures from [5].

\section{FINDINGS AND DISCUSSION}

\section{A. Findings}

TABLE I. KASEPUHAN

\begin{tabular}{|c|l|l|}
\hline No & \multicolumn{1}{|c|}{ Cultural words } & Number \\
\hline 1 & Social & 7 \\
\hline 2 & Ecology & 1 \\
\hline 3 & Material & 5 \\
\hline
\end{tabular}

From 1 above, it can be seen that there are 7 social cultural word, 1 ecology cultural word and 5 materials cultural word.

TABLE II. PETILASAN NYI MAS GANDASARI

\begin{tabular}{|l|l|l|}
\hline No & \multicolumn{1}{|c|}{ Cultural words } & Number \\
\hline 1 & Material & 5 \\
\hline 2 & Social & 12 \\
\hline 3 & Customary Culture, Ceremonies and Concepts & 6 \\
\hline
\end{tabular}

Table 2 shows that there are 5 materials cultural word, 12 social cultural word and 6 customary culture, ceremonies and concept.

TABLE III. PLANGON

\begin{tabular}{|l|l|l|}
\hline No & \multicolumn{1}{|c|}{ Cultural words } & Number \\
\hline 1 & Ecology & 1 \\
\hline 2 & Social & 3 \\
\hline 3 & Material & 2 \\
\hline
\end{tabular}

Table 3 shows that there is 1 ecology cultural word, 3 social cultural word and 2 materials cultural word.

TABLE IV. PUSER BUMI

\begin{tabular}{|l|l|l|}
\hline No & \multicolumn{1}{|c|}{ Cultural words } & Number \\
\hline 1 & Material & 3 \\
\hline 2 & Social & 5 \\
\hline
\end{tabular}

Table 4 shows that there are 3 materials cultural word and 5 social cultural word.

TABLE V. SUNYARAGI

\begin{tabular}{|l|l|l|}
\hline No & \multicolumn{1}{|c|}{ Cultural words } & Number \\
\hline 1 & Social & 5 \\
\hline 2 & Material & 6 \\
\hline
\end{tabular}

Table 5 shows that there are 5 social cultural word and 6 materials cultural word.

TABLE VI. TRANSLATION PROCEDURE

\begin{tabular}{|l|l|l|}
\hline No & \multicolumn{1}{|c|}{ Procedures } & Number \\
\hline 1 & Transference & 38 \\
\hline 2 & Cultural equivalent & 10 \\
\hline 3 & Descriptive & 7 \\
\hline 4 & Couplet & 6 \\
\hline
\end{tabular}

Table 6 shows that there are 38 transference procedure, 10 cultural equivalent procedures, 10 descriptive procedures and 6 couplet procedure.

\section{B. Discussion}

according to the issues in this study that is about translating cultural words in the culture of Cirebon with 5 samples taken from Cirebon culture: Kasepuhan, Petilasan Nyi Mas Gandasari, Plangon, Puser Bumi, and Sunyaragi. Based on the theory of Newmark in translating cultural equivalence, 61 data have been found included in cultural equivalence which are included in Social Culture 32 data, Ecology Culture 2 data, Material Culture 21 data, and Concept Ceremony, Indigenous Custom Culture 6 data [5]. After that, the data is also classified based on the procedure or translation technique used. In this study, the translation technique used is the translation theory from Newmark. Researchers only found 4 translation procedure or techniques according to Newmark: Transference, Literal, Descriptive and Couplet (mixed). According to the tables above, there are 38 cultural words translated by the Transference procedure [5]. Then, there is the cultural equivalent in which there are 10 data words of culture that are 
translated with this procedure. In addition, there are 7 data or cultural words that used Descriptive procedure and 6 data that used couplet procedure.

\section{CONCLUSION}

In this research, the writer concluded that the result of the equivalence of the translation of the word culture in 5 texts of Cirebon culture: Kasepuhan, Petilasan Nyi Mas Gandasari, Plangon, Puser Bumi, dan Sunyaragi. Based on the theory of Newmark in translating cultural equivalence, 61 data have been found included in cultural equivalence which are included in Social Culture 32 data, Ecology Culture 2 data, Material Culture 21 data, and Concept Ceremony, Indigenous Custom Culture 6 data [5]. After that, the data is also classified based on the procedure or translation technique used. In this study, the translation technique used is the translation theory from Newmark [5]. Researchers only found 4 translation procedure or techniques according to Newmark [5]: Transference, Literal, Descriptive and Couplet (mixed). According to the tables above, there are 38 cultural words translated by the Transference procedure. Then, there is the cultural equivalence in which there are 10 data words of culture that are translated with this procedure. In addition, there are 7 data or cultural words that used Descriptive procedure and 6 data that used couplet procedure.

\section{REFERENCES}

[1] L. Venuti, The Translator's Invisibility. A History of Translation. London: Routledge, 1995

[2] U. Lotman, 212; emphasis mine - H. C., 1978.
[3] D. Puspitasari, E.M.I. Lestari, and N.I. Syartani, "Kesepadanan Penerjemahan Kata Bermuatan Budaya Jepang Ke Dalam Bahasa Indonesia," Jurnal Izumi, vol. 3, no. 2, 2014

[4] Nuryadi, "Penerjemahan Kata-Kata Budaya Bahasa Indonesia ke Dalam Bahasa Inggris,” Jurnal Makna, vol. 1, no. 1, 2016.

[5] P. Newmark, A Text Book of Translation. New York: Prentice Hall International, 1998.

[6] B.H. Hoed, Penerjemahan dan Kebudayaan. Jakarta: Pustaka Jaya, 2006.

[7] H. Vermer, "Is Translation a lingustic or a Culture Process?" [Online]. Retrieved from https://periodocoss,ufsc.br/index.php/desterro/article/download/8570/81 12

[8] P. Krisnawati and A.S. Ida, "Strategi Penerjemahan Istilah Budaya Bali Pada Media Promosi Pariwisata di Kabupaten Badung," Litera Jurnal Bahasa dan Sastra, vol. 5, no. 1, 2019.

[9] E.A. Nida and R.T. Charles, The Theory and Practice of Translation. Leiden: E.J. Brill, 1974.

[10] M.L. Larson, Meaning Based Translation: A Guide to Cross Language equivalence. Lanham: University Press of America, 1984.

[11] M. Nurjana, "Penerjemahan Kata Budaya dalam Laskar Pelangi ke Dalam Novel Bahasa Jepang Niji No Shoonentachi,” Paradigma Jurnal Kajian Budaya, vol. 7, no. 1, 2017.

[12] Kardimin, "Ragam Penerjemahan," Jurnal Studi Islam, vol. 2, no. 1, 2017.

[13] Koentjaraningrat, Pengantar Antropolgi I. Jakarta: PT Rineka Cipta, 2014.

[14] J.C. Catford, A Linguistic Theory of Translation. Oxford: Oxford University Press, 1965.

[15] E.A. Nida, “ Linguistic and Ethnology in Translation Problems” dalam Dell Hymes(ed), Language in Culture and Society. New York: Harper and Row Publisher, 1996.

[16] F. Djajasudarma, Metode Linguistik: Ancangan Metode Penelitian dan Kajian. Jakarta: Refika Aditama, 2010.

[17] D. Hardiyanti and Y.O. Maya "Penerjemahan Kosa Kata Budaya Indonesia dalam Rubrik Life Lines di Harian The Jakarta Post," Unpublished.

[18] J.W. Creswell, Research Design : Qualitative, Quantitative, and mixed methods approaches. Thousand Oaks, California. SAGE Publications, 2007 